\title{
Large-scale production and antiviral efficacy of multi-target double-stranded RNA for the prevention of white spot syndrome virus (WSSV) in shrimp
}

\author{
Thitiporn Thammasorn ${ }^{1}$, Pakkakul Sangsuriya ${ }^{2,3}$, Watcharachai Meemetta', Saengchan Senapin ${ }^{1,3}$,
} Sarocha Jitrakorn ${ }^{1,3}$, Triwit Rattanarojpong ${ }^{4}$ and Vanvimon Saksmerprome ${ }^{1,3^{*}}$

\begin{abstract}
Background: RNA interference (RNAi) is a specific and effective approach for inhibiting viral replication by introducing double-stranded (ds)RNA targeting the viral gene. In this study, we employed a combinatorial approach to interfere multiple gene functions of white spot syndrome virus (WSSV), the most lethal shrimp virus, using a single-batch of dsRNA, so-called "multi-WSSV dsRNA." A co-cultivation of RNase-deficient E. coli was developed to produce dsRNA targeting a major structural protein (VP28) and a hub protein (WSSV051) with high number of interacting protein partners.

Results: For a co-cultivation of transformed E. coli, use of Terrific broth (TB) medium was shown to improve the growth of the E. coli and multi-WSSV dsRNA yields as compared to the use of Luria Bertani (LB) broth. Co-culture expression was conducted under glycerol feeding fed-batch fermentation. Estimated yield of multi-WSSV dsRNA $(\mu \mathrm{g} / \mathrm{mL}$ culture) from the fed-batch process was 30 times higher than that obtained under a lab-scale culture with LB broth. Oral delivery of the resulting multi-WSSV dsRNA reduced \% cumulative mortality and delayed average time to death compared to the non-treated group after WSSV challenge.

Conclusion: The present study suggests a co-cultivation technique for production of antiviral dsRNA with multiple viral targets. The optimal multi-WSSV dsRNA production was achieved by the use of glycerol feeding fed-batch cultivation with controlled $\mathrm{pH}$ and dissolved oxygen. The cultivation technique developed herein should be feasible for industrial-scale RNAi applications in shrimp aquaculture. Interference of multiple viral protein functions by a single-batch dsRNA should also be an ideal approach for RNAi-mediated fighting against viruses, especially the large and complicated WSSV.
\end{abstract}

Keywords: Co-cultivation, White spot syndrome virus, dsRNA, Shrimp, VP28, WSSV051

\section{Background}

White spot syndrome virus (WSSV), a major pathogen with high infectivity and mortality, has been a serious threat for penaeid shrimp aquaculture in the past two decades. WSSV is a large double-stranded DNA virus with the approximate genome size of $300 \mathrm{kbp}$ [1-3].

\footnotetext{
* Correspondence: vanvimon.sak@biotec.or.th

${ }^{1}$ Center of Excellence for Shrimp Molecular Biology and Biotechnology,

Faculty of Science, Mahidol University, Bangkok 10400, Thailand

${ }^{3}$ National Center of Genetic Engineering and Biotechnology, (BIOTEC),

Thailand Science Park, Pathum Thani 12120, Thailand

Full list of author information is available at the end of the article
}

Most of their putative translated gene products have no homology to other proteins from viruses or host cells. The uniqueness of WSSV therefore classified the virus into its own family Nimaviridae and genus Whispovirus [4]. Several aspects including morphology and pathogenicity of WSSV have been intensively studied to seek prevention and therapeutic treatment. The viral control strategies were included administration of recombinant WSSV proteins and DNA vaccine based constructs [1, 5-8]. Application of immunostimulants were also introduced to shrimp to fight 
against WSSV infection $[9,10]$. Nevertheless, no practical and effective methods have been established to control WSSV yet.

Application of RNA interference (RNAi) or doublestranded (ds)RNA-mediated viral inhibition has been shown to be a promising anti-WSSV strategy [11-15]. In this study, we proposed a combinatorial approach to interfere multiple WSSV gene expression using a single batch of dsRNA (hereafter called "multi-WSSV dsRNA"). Targeting multiple viral targets by dsRNA could possibly result in additive inhibition; however, more importantly, this approach should lower the chance of viral escape that needs to have multiple resistance mutations within the dsRNA targets occurred simultaneously [16]. The target viral genes in this study include a major structural protein (VP28) and a hub protein (WSSV051). VP28 is involved in the viral entry to shrimp cells, and injection of dsRNA corresponding to VP28 was shown to effectively protect shrimp against the virus $[11,13,14]$. Oral administration of VP28-specific dsRNA was demonstrated as a potential therapeutic method by improving shrimp survival rate after WSSV challenge [17]. WSSV051, also known as structural protein VP55, has been recently identified as one of the hub proteins from the WSSV protein-protein interaction network [15]. The hub function is to hold the proteins together in the network therefore knock-down of WSSV hubs would be expected to collapse WSSV functions, and silencing this gene by specific dsRNA could delay shrimp mortality after WSSV infection [15].

Here, a co-cultivation of RNase-deficient E. coli was developed to produce multi-WSSV dsRNA, and largescale production of the multi-WSSV dsRNA was optimized through a glycerol feeding fed-batch fermentation. Feed pellets formulated with the multi-WSSV dsRNA were prepared according to the method described by Saksmerprome et al. [18], and their antiviral efficacy was also examined.

\section{Methods}

Co-cultivation of two strains of RNase-deficient $E$. coli to produce dsRNA targeting multiple WSSV genes

Construction of hairpin expression vector targeting VP28 (GenBank no. AY422228.1, nucleotides 8-189) was developed according to the method described by Saksmerprome et al. [19]. The plasmid encoding WSSVVP28 of 181-bp was used as a template for PCR. Primers used for amplification of DNA template for dsRNAVP28 synthesis are VP28F (5' TTT CTT TCA CTC TTT CGG TCG T 3') and VP28R1 (5' GCC TGA TCC AAC CTC AGC AGT C 3'). The conditions for PCR amplification were as follows: $3 \mathrm{~min}$ at $94{ }^{\circ} \mathrm{C}, 35$ cycles of $30 \mathrm{~s}$ at $94{ }^{\circ} \mathrm{C}, 30 \mathrm{~s}$ at $53{ }^{\circ} \mathrm{C}$ and $30 \mathrm{~s}$ at $72{ }^{\circ} \mathrm{C}$ and extension at $72{ }^{\circ} \mathrm{C}$ for $5 \mathrm{~min}$. The other construct targeting WSSV051 (GenBank no. AF440570, nucleotides 28034-28316) was performed with modified protocols from Sangsuriya et al. [15]. An amplified amplicon of $393 \mathrm{bp}$ was obtained from a PCR reaction using specific primers: 051siF (5' TTC AGG GCG GCT ATC TTA TG) and 051siR2 (5' TCA TCT TCT TCC ATG ACA TC3') and DNA extracted from WSSV-infected gill tissues as template. The conditions for PCR amplification were as follows: $3 \mathrm{~min}$ at $94{ }^{\circ} \mathrm{C}, 35$ cycles of $30 \mathrm{~s}$ at $94{ }^{\circ} \mathrm{C}, 30 \mathrm{~s}$ at $55{ }^{\circ} \mathrm{C}$ and $30 \mathrm{~s}$ at $72{ }^{\circ} \mathrm{C}$ and extension at $72{ }^{\circ} \mathrm{C}$ for $5 \mathrm{~min}$. The PCR product was then purified and cloned in a sense orientation downstream of the T7 promoter of pDrive vector (QIAGEN). Subsequently, an amplicon of 283 bp obtained using a primer set harboring XbaI and HindIII restriction sites (XbaI-051siF: 5' GC TCTAGA TTC AGG GCG GCT ATC TTA 3' and HindIII-051siR3: 5' AC AAGCTT AAA GAA AAC CCC TTC TGG 3') was cloned in an antisense orientation downstream of the first fragment. The hairpin constructs containing both sense and antisense strands were then verify by DNA sequencing.

Each recombinant plasmid was transformed into RNase III-deficient E. coli HT115 (DE3) for long dsRNA production. Two types of cultivation medium, Luria Bertani (LB) and Terrific broth (TB), were used to achieve the optimal production of bacteria cells and dsRNA. LB medium consisted $1 \%(\mathrm{w} / \mathrm{v})$ tryptone, $0.5 \%(\mathrm{w} / \mathrm{v})$ yeast extract, and $1 \%(\mathrm{w} / \mathrm{v}) \mathrm{NaCl}$. Composition of TB medium was $1.2 \%$ (w/v) tryptone, $2.4 \%(\mathrm{w} / \mathrm{v})$ yeast extract, $0.72 \mathrm{M}$ potassium phosphate (dibasic), $0.17 \mathrm{M}$ potassium phosphate (monobasic), and $0.4 \%$ (v/v) glycerol. For a starter culture, a single transformant colony for each dsRNA population was inoculated into $3 \mathrm{~mL}$ of either $\mathrm{LB}$ or TB medium in the presence of $100 \mu \mathrm{g} / \mathrm{mL}$ ampicillin and $12 \mu \mathrm{g} / \mathrm{mL}$ tetracycline. The culture was shaken at $250 \mathrm{rpm}, 37^{\circ} \mathrm{C}$ until $\mathrm{OD}_{600 \mathrm{~nm}}$ of 3.5-4.0 was obtained (approximately $16 \mathrm{~h}$ ). Co-inoculation was subsequently performed at the ratio 1:100 (v/v) in fresh medium. The co-culture was shaken for $8 \mathrm{~h}$ at $37^{\circ} \mathrm{C}$, and was collected for analysis.

\section{Fermentation processes for large-scale production of multi-WSSV dsRNA}

Large-scale production of multi-WSSV dsRNA was conducted in a 10-L bioreactor at Biochemical Engineering and Pilot Plant Research and Development Unit (BEC) of KMUTT, Thailand. The starter culture was prepared as described above. Co-inoculation was performed at the ratio 1:40 (v/v) in 5-L fresh medium containing $100 \mu \mathrm{g} /$ $\mathrm{mL}$ ampicillin and $12 \mu \mathrm{g} / \mathrm{mL}$ tetracycline. For both batch and fed-batch fermentation, temperature was maintained at $37{ }^{\circ} \mathrm{C}$ and $\mathrm{pH}$ was kept at 7.0 using $1 \mathrm{M} \mathrm{NH}_{4} \mathrm{OH}$. Dissolved oxygen (DO) was controlled at $30 \%$ of air saturation. Batch fermentation was run for $8 \mathrm{~h}$, and $50 \mathrm{ml}$ of the culture were collected for analysis. The remaining 
culture underwent the fed-batch process by feeding $500 \mathrm{~g} / \mathrm{L}$ of glycerol as the carbon source at the rate of $2.9 \mathrm{~mL} / \mathrm{h}$. Fed-batch fermentation was continued until sequential increasing of DO (\%) value was indicated as the decline phase (or cultivation time of $30 \mathrm{~h}$ ), and $50 \mathrm{~mL}$ of fed-batch culture were collected for analysis.

Cell concentrations $(\mathrm{CFU} / \mathrm{mL})$ obtained from lab-scale and large-scale fermentation were determined by measuring UV absorbance at $600 \mathrm{~nm}$, and $1 \mathrm{OD}_{600 \mathrm{~nm}}$ is equivalent to $10^{9} \mathrm{CFU} / \mathrm{mL}$. RNA extraction was performed using phenol-chloroform method [20]. Reverse transcription (RT)-PCR and $1.5 \%$ agarose gel electrophoresis were performed to indicate the presence of WSSV-specific dsRNA. The primer pairs for detection of WSSV05-dsRNA are XbaI-051siF and HindIII-051siR3, for detection of VP28-dsRNA are VP28F and VP28R1. The RT-PCR conditions to detect WSSV051-dsRNA were as follows: $5 \mathrm{~min}$ at $50{ }^{\circ} \mathrm{C}, 5 \mathrm{~min}$ at $94{ }^{\circ} \mathrm{C}, 35$ cycles of $10 \mathrm{~s}$ at $94{ }^{\circ} \mathrm{C}, 30 \mathrm{~s}$ at $55{ }^{\circ} \mathrm{C}$ and $30 \mathrm{~s}$ at $68{ }^{\circ} \mathrm{C}$ and extension at $68{ }^{\circ} \mathrm{C}$ for $5 \mathrm{~min}$, whereas VP28-dsRNA detection were as follows: $5 \mathrm{~min}$ at $50{ }^{\circ} \mathrm{C}, 5 \mathrm{~min}$ at $94{ }^{\circ} \mathrm{C}, 35$ cycles of $10 \mathrm{~s}$ at $94{ }^{\circ} \mathrm{C}, 30 \mathrm{~s}$ at $53{ }^{\circ} \mathrm{C}$ and $30 \mathrm{~s}$ at $68{ }^{\circ} \mathrm{C}$ and extension at $68{ }^{\circ} \mathrm{C}$ for $5 \mathrm{~min}$. Nuclease digestion experiments using RNase A and RNase III were performed as described in Saksmerprome et al. [19] to examine quality and integrity of each dsRNA production. The amount of dsRNA was quantitated by measuring UV absorbance at $260 \mathrm{~nm}$, and dsRNA concentration extracted from $1 \mathrm{~mL}$ culture was calculated in $\mu \mathrm{g} / \mu \mathrm{l}$.

\section{Feed preparation}

Four formulas of feed, with different types and doses of dsRNA, were tested; 1) $6 \mathrm{mg}$ of WSSV051-dsRNA, 2) $6 \mathrm{mg}$ of VP28-dsRNA, 3) $6 \mathrm{mg}$ of multi-WSSV dsRNA and 4) $12 \mathrm{mg}$ of multi-WSSV dsRNA. For detailed feed preparation, the commercial shrimp feed (OMEG 1704 S, BETAGRO) was ground using a blender. One kilogram of mashed feed was mixed with $500-\mathrm{mL}$ of the co-culture thoroughly. Feed mixture was pelleted by pressing through $10-\mathrm{mL}$ syringe ( $2 \mathrm{~mm}$ in diameter), and the feed pellets were dried at $60{ }^{\circ} \mathrm{C}$ in hot air oven for $24 \mathrm{~h}$. To indicate the presence dsRNA in feed, extracted RNA from $0.1 \mathrm{~g}$ feed pellets were subjected to RT-PCR using WSSV051- and VP28-specific primers. The same procedure was repeated on the formulated feed kept at $20-25{ }^{\circ} \mathrm{C}$ for 7 months to examine dsRNA stability in feed.

\section{Oral administration of multi-target dsRNA and WSSV challenge}

Penaeus vannamei shrimp with the average size of 3$5 \mathrm{~g}$ were acclimatized for 3 days in 15 ppt of artificial seawater with aeration, and were arbitrarily divided into 6 groups $(n=10)$ with 3 replicates of each group. Four groups received the dsRNA-formulated feed, while the
WSSV-positive and negative controls received commercial feed without modification. Feeding dose rate was at $4 \%$ of their body weight, and shrimp were fed twice a day. Individual 5-g shrimp in groups that received single- and double-dose formulas would receive 1.2 and $2.4 \mu \mathrm{g}$ dsRNA per meal at the most, respectively. After 5-day feeding, all animals, except the WSSV-negative control group, were injected with $10^{5}$ copies of WSSV $\left(\mathrm{LD}_{50}=4\right.$ days) per shrimp. The animals were fed continuously with the assigned feed for the next 7 days. Shrimp mortality of each group was recorded, and the average time to death was calculated accordingly. Data on average time to death was analyzed by t-test analysis using SPSS18.0 software, $P<0.05$.

\section{Results and Discussion}

A single co-cultivation with Terrific Broth medium resulted in high cell density and dsRNA yield

The effect of culture medium on productivity of E. coli expression system has been studied by varying various media to achieve the optimal production of bioactive compounds $[21,22]$, indicating the need for optimization of culture conditions when attempting cultivation of new species. Previous work by our group demonstrated the production of dsRNA against shrimp viruses in RNase-deficient $E$. coli using LB broth medium [18, 19, 23, 24]. A single population of dsRNA against an individual shrimp viral gene is produced in the range of a few micrograms per $100 \mathrm{~mL} E$. coli culture under a lab-scale experiment. In this study, we tested to see if use of Terrific broth (TB), a culture medium that is commonly used in culture conditions for protein overexpression $[22,25,26]$ would enhance the productivity of co-cultivated bacteria as compared to the original condition with LB broth. For a small-scale cultivation, final cell density $(\mathrm{CFU} / \mathrm{mL})$ and dsRNA production $(\mu \mathrm{g} / \mathrm{mL}$ culture) in the culture with TB medium were both approximately $2 x$ those of the culture with LB broth (Table 1). The enhanced cell growth and dsRNA yield under TB condition could be explained as follows. TB is a nutritionally rich medium containing a 4.8-time higher yeast extract relative to LB broth. Yeast extract is a main component for the growth of microorganism. It contains nitrogenous compounds, carbon, sulfur, trace nutrients, vitamin B complex and other important growth factors. The additional $0.4 \%$ glycerol is also provided in TB broth as an extra carbon source. Moreover, TB medium contains $\mathrm{K}_{2} \mathrm{HPO} 4$ and $\mathrm{KH}_{2} \mathrm{PO} 4$ which function as buffer medium, therefore the $\mathrm{pH}$ of the TB medium is maintained to optimize culture condition during the cell growth $[21,22,25,27]$.

\section{Fed-batch glycerol feeding strategy for large-scale production of multi-WSSV dsRNA}

Two fermentation processes in 10-L bioreactor were employed using TB medium for large-scale production of 
Table 1 Determination of cell concentrations and dsRNA yields obtained from a single co-cultivation of RNase-deficient E. coli

\begin{tabular}{llllcl}
\hline Production scale & Type of process & Medium & Cell density $\left(\times 10^{9} \mathrm{CFU} / \mathrm{mL}^{\mathrm{a}}\right)$ & dsRNAyield $\left(\mu \mathrm{g} / \mathrm{mL}^{\mathrm{a}}\right)$ & Incubation time $(\mathrm{hr}$. $)$ \\
\hline Laboratory & - & LB & $2.4 \pm 0.2$ & $2.6 \pm 0.8$ & 8 \\
& - & TB & $4.5 \pm 0.1$ & $6.2 \pm 0.2$ & 8 \\
Large & Batch & TB & $21.1 \pm 2.9$ & $3.4 \pm 0.5$ & 8 \\
& Fed-batch & TB & $36.2 \pm 4.5$ & $95.0 \pm 21.5$ & 30 \\
\hline
\end{tabular}

${ }^{\mathrm{a}} 1 \mathrm{~mL}$ of bacteria culture

multi-WSSV dsRNA. For a conventional batch fermentation, the final cell density $(\mathrm{CFU} / \mathrm{mL})$ at 8 -h cultivation time significantly increased, although dsRNA yield $(\mu \mathrm{g} / \mathrm{mL})$ was half of that obtained in the lab-scale cultivation with TB broth (Table 1). Without additional supplements under the continuous fermentation process, lack of nutrients in high-density culture could limit dsRNA production. In addition, formation of inhibitory factors, such as acetate by-product of aerobic fermentation in the presence of high concentration of carbon source, could have negative effects on growth and E. coli and productivity of its products [28-30]. Slow glycerol feeding fed-batch fermentation with controlled dissolved oxygen and pH stability is recommended to improve high cell density and product yields by maintaining the optimal specific growth rate during process $[28,29]$. The propagation technique is widely used for production of various bioactive products, including DNA plasmids for vaccine and recombinant proteins $[25,31,32]$. As shown in Table 1 , cell density of $36.2 \times 10^{9} \pm 4.5 \times 10^{9} \mathrm{CFU} / \mathrm{mL}$ was obtained at 30 -h fed-batch process, producing approximately $95.0 \pm 21.5 \mu \mathrm{g}$ of multi-WSSV dsRNA. The amount of dsRNA as determined from the 1-mL fed-batch culture was almost 30 times higher than the yield obtained under the batch fermentation. RT-PCR followed by $1.5 \%$ agarose gel electrophoresis indicated the presence of dsRNA targeting VP28 (181 bp) and dsRNA targeting WSSV051 (283 bp) in all experiments (Fig. 1a). Evidence for doublestranded nature of the synthesized dsRNAs was obtained from nuclease digestion experiments using RNase A and RNase III depicted in Fig. 1a. Both VP28- and WSSV051dsRNA were proved to be genuine since they were digested by RNase III but not by RNase A (Fig. 1b).

\section{Oral administration of feed formulated with multi-WSSV dsRNA reduced shrimp mortality and delayed time to death after WSSV challenge}

To test the protective efficacy against the virus of multiWSSV dsRNA relative to a single gene-targeted dsRNA, feed were formulated to contain single (VP28 or WSSV051) and multiple types (multi-WSSV) with the same quantity of total dsRNA (6 mg each per $1-\mathrm{kg}$ feed). The multi-WSSV formulated feed kept at room temperature for 7 months was examined by RT-PCR, and was found to still maintain both VP28- and
WSSV051-dsRNA (Fig. 2). All types of the formulated feed were given to shrimp for 5 days prior to WSSV challenge. The dsRNA-treated groups were monitored in parallel to the control animals for their mortality rate (Fig. 3a) and average time to death, i.e. time when the highest accumulated mortality observed (Fig. 3b). As expected, the WSSV-positive control group showed mortality at 1 day post infection (dpi), and cumulative mortality reached $100 \%$ by the 7 th dpi, whereas no cumulative morality observed in the negative-WSSV group at the end of experiment. Comparative efficacy of VP28- and WSSV051- and multi-WSSV dsRNA was also investigated at the same dsRNA quantity per $\mathrm{kg}$ feed. WSSV051-dsRNA group showed cumulative mortality of $60 \%$ at $7 \mathrm{dpi}$, and average time to death of $6 \mathrm{~d}$., affording the least protection among the three groups examined in this study. Viral protective effect of multi-WSSV dsRNA appeared to be intermediate between those of VP28- and WSSV051-dsRNA. The variation of antiviral efficacy might be due to the different targeted genes and their functions in host cells. VP28 is functionally involved in entry step into shrimp cells therefore suppression of this gene resulted in inhibition of viral infection. Although WSSV051 was identified as hub protein, its actual function in shrimp is not yet revealed. To increase efficiency of viral inhibition by WSSV051 dsRNA alone, its higher quantity might be required.

Several WSSV genotypes have been extensively revealed, and this genetic variation is essential to describe viral epidemiology and evolutionary (see review by Shekar M et al. [33]). For instance, the complete genomes of three strains of WSSV-TH (AF369029), WSSV-CN (AF332093) and WSSV-TW (AF440570) were reported, indicating the genetic variations including (i) a large deletion of $13.2 \mathrm{~kb}$ in the WSSV-TH; (ii) a genetically variable region found in the WSSV-TH; (iii) an insert of transposable elements in the WSSV-TW; (iv) variation in the number of repeat units within homologous regions and direct repeats; (v) insertions or deletions of single nucleotide mutations and single nucleotide polymorphisms [34]. The differences in genetic content have also been accounted for viral virulence [35-37]. Moreover, mixed-genotypes of WSSV have been investigated in both experimental and natural infections $[35,36,38]$. Therefore, to combat WSSV infection that might cause by different strains and 


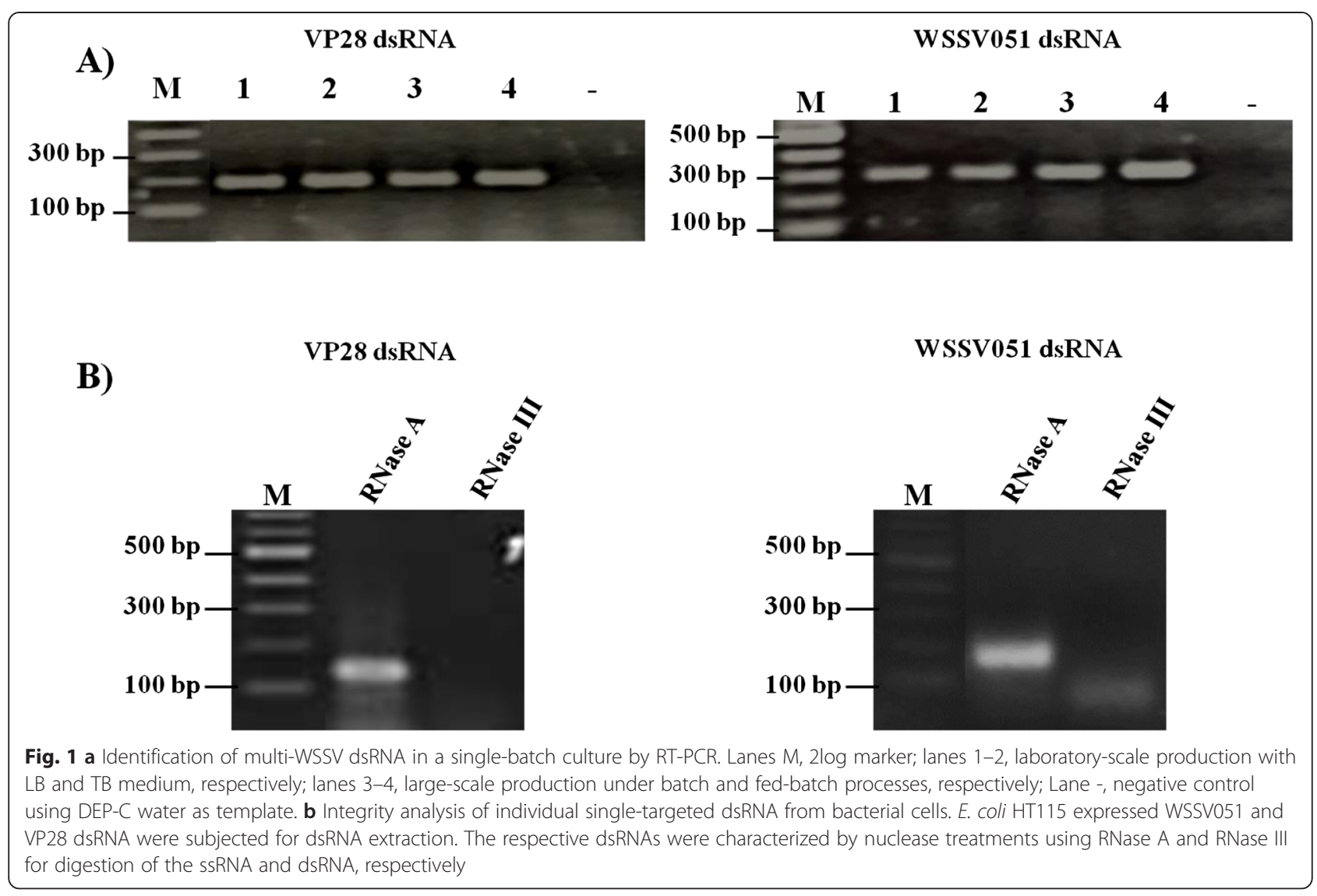

virulence, multiple targets would be a better approach to control viral escape.

Dose dependent effect of dsRNA was also assessed by doubling dose of multi-WSSV in the last formula $(12 \mathrm{mg}$ per $1-\mathrm{kg}$ feed). Throughout the experimental time, \% mortality of the groups received multi-WSSV dsRNA, at either single or double dose, was significantly lower than that of the WSSV-positive group that did not receive any dsRNA. Average time to death of both single- and double-dose multi-WSSV dsRNA groups were delayed to 7-8 days, while that of the viral positive control was approximately 5 days. Increasing dose of multi-WSSV, from 6 to $12 \mathrm{mg} / \mathrm{kg}$ feed, slightly reduced \% mortality. It would be interesting to see if significant dose-dependent

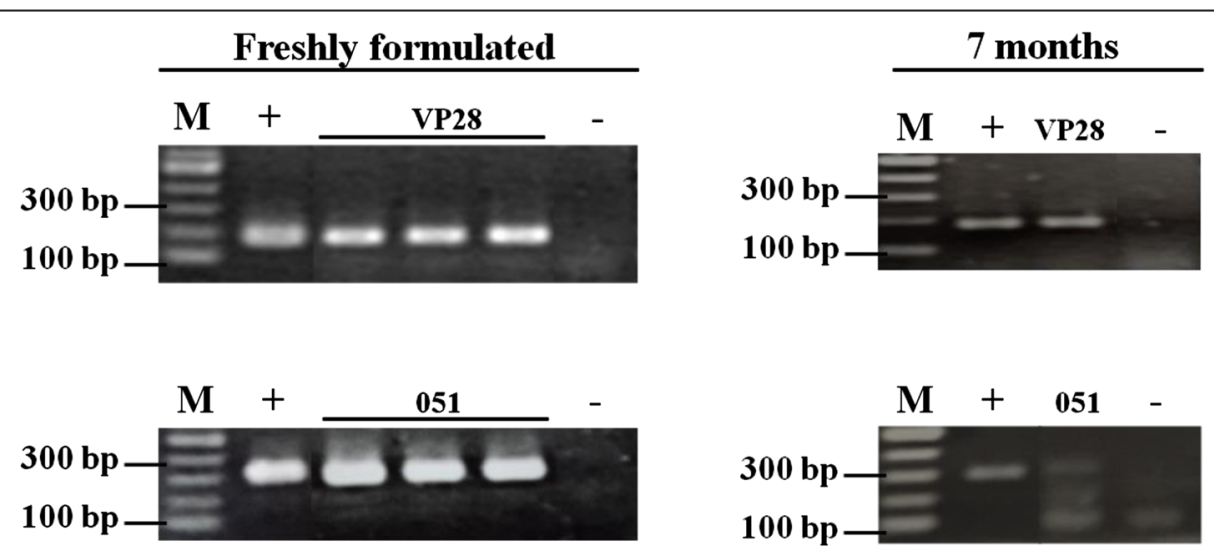

Fig. 2 Detection of multi-WSSV dsRNA in the freshly-formulated feed and the formulated-feed stored at $20-25^{\circ} \mathrm{C}$ for 7 months. Lanes VP28, VP28-dsRNA; 051, WSSV051-dsRNA; +, positive control using plasmid expressing hairpin VP28 and WSSV051 as templates; -, negative control using DEP-C water as template; M, 2-log DNA ladder 
A)

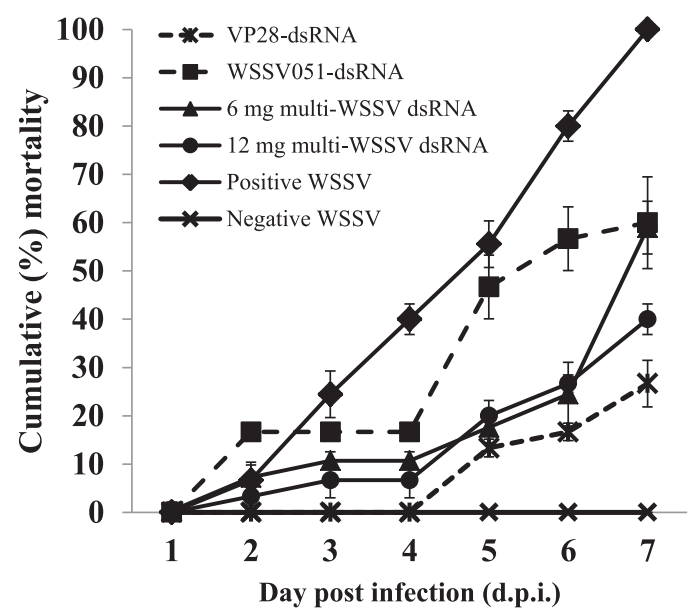

B) Mean time to death

\begin{tabular}{|l|c|}
\hline \multicolumn{1}{|c|}{ Group } & Mean \pm S.E. \\
\hline VP28-dsRNA & $9.2 \pm 0.5$ \\
\hline WSSV051-dsRNA & $6.3 \pm 0.5$ \\
\hline 6 mg multi-WSSV dsRNA & $7.5 \pm 0.5$ \\
\hline 12mg multi-WSSV dsRNA & $7.7 \pm 0.4$ \\
\hline Positive WSSV & $4.9 \pm 0.2$ \\
\hline
\end{tabular}

Fig. 3 a Cumulative mortality rate of shrimp in each group after WSSV challenge. b Calculated mean time to death of each group

effect of multi-WSSV dsRNA would be observed under a farm-scale experiment as previously reported by Saksmeprome et al. [18].

\section{Conclusions}

This report described the methodology on using cocultivation approach for large-scale production of dsRNA targeting multiple WSSV genes. First, a single cocultivation with Terrific Broth medium, where RNasedeficient bacteria expressing different types of dsRNA are simultaneously inoculated, is efficient and time-saving for production of multi-target dsRNA. For large-scale production, fed-batch fermentation with glycerol feeding should be suitable for industrial use of RNAi in shrimp aquaculture. The amount of dsRNA as determined from fedbatch culture was almost 30 times higher than the yield obtained under the conventional batch fermentation. Interim analysis showed that oral application of multiWSSV dsRNA significantly reduced \% shrimp mortality and delayed time to death relative to the WSSV positive control. Despite the intermediate effect of the multiWSSV dsRNA, compared to the single-targeted dsRNA (VP28 and WSSV051), the use of multiple-target dsRNA should still be encouraged for better controlling the complex WSSV with large genetic variations. Sequence analysis of individual dsRNA components may be necessary to minimize intermolecular interference among them when designing multiple-targeted dsRNA for optimal silencing effect.

\section{Abbreviations}

\%: Per cent; bp: Base pair; CFU: Colony forming unit; ${ }^{\circ} \mathrm{C}$ : Degree centigrade; DEP-C water: Diethylpyrocarbonate water; dsRNA: Double stranded RNA; mL: Milliliter; M: Molar; $\mu l:$ Micro liter; ng: Nano gram; nm: Nano metre;
OD: Optical density; RT-PCR: Reverse transcriptase-polymerase chain reaction; rpm: Revolution per minute; v/v: Volume by volume.

\section{Competing interests}

The authors declare that they have no competing interests.

\section{Authors' contributions}

This work was done at Centex shrimp, Faculty of Science, Mahidol University and Biochemical Engineering and Pilot Plant Research and Development Unit (BEC) of KMUTT, Thailand. WSSV targets were selected by VS and SS. Construction of hairpin expression vectors were performed by PS and TT with the kind help of TR and SJ. Co-cultivation and fermentation processes were conducted by $\Pi$ T and PS. Results was analyzed by $T$ and WM under the supervision of VS and SS. Manuscript preparation was done by VS and $\pi$ T. All authors read and approved the final manuscript.

\section{Acknowledgments}

The authors would like to thank Asst. Prof. Somchai Chauvatcharin, Department of Biotechnology, Faculty of Science, Mahidol University for valuable discussion on fermentation conditions. Shrimp were provided by Dr. Bunlung Nuangsaeng, Faculty of Marine technology, Burapha University, Chanthaburi campus. This work was funded by Mahidol University, and the Thai National Center of Biotechnology and Genetic Engineering (BIOTEC).

\section{Author details}

${ }^{1}$ Center of Excellence for Shrimp Molecular Biology and Biotechnology, Faculty of Science, Mahidol University, Bangkok 10400, Thailand.

${ }^{2}$ Department of Biochemistry, Center of Excellence for Molecular Biology and Genomics of Shrimp, Faculty of Science, Chulalongkorn University, Bangkok, Thailand. ${ }^{3}$ National Center of Genetic Engineering and Biotechnology, (BIOTEC), Thailand Science Park, Pathum Thani 12120, Thailand. ${ }^{4}$ Department of Microbiology, Faculty of Science, King Mongkut's University of Technology Thonburi, Bangkok 10140, Thailand.

Received: 30 December 2014 Accepted: 27 November 2015 Published online: 01 December 2015

\section{References}

1. van Hulten MCW, Witteveldt J, Peters S, Kloosterboer N, Tarchini R, Fiers M, et al. The white spot syndrome virus DNA genome sequence. Virology. 2001;286(1):7-22.

2. Yang F, He J, Lin X, Li Q, Pan D, Zhang X, et al. Complete genome sequence of the shrimp white spot bacilliform virus. J Virol. 2001;75(23): 11811-20. 
3. Chen L-L, Wang H-C, Huang C-J, Peng S-E, Chen Y-G, Lin S-J, et al. Transcriptional analysis of the DNA polymerase gene of shrimp white spot syndrome virus. Virology. 2002;301(1):136-47.

4. Mayo MA. A summary of taxonomic changes recently approved by ICTV. Arch Virol. 2002;147(8):1655-6.

5. Witteveldt J, Vlak JM, Hulten MCW. Increased tolerance of Litopenaeus vannamei to white spot syndrome virus (WSSV) infection after oral application of the viral envelope protein VP28. Dis Aquat Organ. 2006; 70(1-2):167-70.

6. Satoh J, Nishizawa T, Yoshimizu M. Protection against white spot syndrome virus (WSSV) infection in kuruma shrimp orally vaccinated with WSSV rVP26 and rVP28. Dis Aquat Organ. 2008;82(2):89-96.

7. Rout N, Kumar S, Jaganmohan S, Murugan V. DNA vaccines encoding viral envelope proteins confer protective immunity against WSSV in black tiger shrimp. Vaccine. 2007;25(15):2778-86.

8. Lu Y, Liu J, Jin L, Li X, Zhen Y, Xue H, et al. Passive protection of shrimp against white spot syndrome virus (WSSV) using specific antibody from egg yolk of chickens immunized with inactivated virus or a WSSV-DNA vaccine. Fish Shellfish Immunol. 2008;25(5):604-10.

9. Citarasu T, Sivaram V, Immanuel G, Rout N, Murugan V. Influence of selected Indian immunostimulant herbs against white spot syndrome virus (WSSV) infection in black tiger shrimp, Penaeus monodon with reference to haematological, biochemical and immunological changes. Fish Shellfish Immunol. 2006;21(4):372-84.

10. Balasubramanian G, Sarathi M, Venkatesan C, Thomas J, Sahul Hameed AS Studies on the immunomodulatory effect of extract of Cyanodon dactylon in shrimp, Penaeus monodon, and its efficacy to protect the shrimp from white spot syndrome virus (WSSV). Fish Shellfish Immunol. 2008;25(6):820-8.

11. Xu J, Han F, Zhang X. Silencing shrimp white spot syndrome virus (WSSV) genes by siRNA. Antiviral Res. 2007;73(2):126-31.

12. Attasart $P$, Kaewkhaw $R$, Chimwai $C$, Kongphom U, Namramoon O, Panyim S. Inhibition of white spot syndrome virus replication in Penaeus monodon by combined silencing of viral rr2 and shrimp PmRab7. Virus Res. 2009; 145(1):127-33.

13. Mejía-Ruíz CH, Vega-Peña S, Alvarez-Ruiz P, Escobedo-Bonilla CM. Doublestranded RNA against white spot syndrome virus (WSSV) vp28 or vp26 reduced susceptibility of Litopenaeus vannamei to WSSV, and survivors exhibited decreased susceptibility in subsequent re-infections. J Invertebr Pathol. 2011;107(1):65-8

14. Sanjuktha M, Stalin Raj V, Aravindan K, Alavandi SV, Poornima M, Santiago TC. Comparative efficacy of double-stranded RNAs targeting WSSV structural and nonstructural genes in controlling viral multiplication in Penaeus monodon. Arch Virol. 2012;157(5):993-8.

15. Sangsuriya $P$, Huang J-Y, Chu Y-F, Phiwsaiya $K$, Leekitcharoenphon $P$, Meemetta W, et al. Construction and application of a protein interaction map for White Spot Syndrome Virus (WSSV). Mol Cell Proteomics. 2014; 13(1):269-82.

16. ter Brake O, Berkhout B. A novel approach for inhibition of HIV-1 by RNA interference: counteracting viral escape with a second generation of siRNAs. J RNAi Gene Silencing. 2005;1(2):56-65.

17. Sarathi M, Simon M, Venkatesan C, Hameed ASS. Oral administration of bacterially expressed VP28dsRNA to protect penaeus monodon from white spot syndrome virus. Marine Biotechnol. 2008;10(3):242-9.

18. Saksmerprome V, Thammasorn $T$, Jitrakorn S, Wongtripop S, Borwornpinyo S, Withyachumnarnkul B. Using double-stranded RNA for the control of Laem-Singh Virus (LSNV) in Thai P. monodon. J Biotechnol. 2013;164(4): 449-53.

19. Saksmerprome V, Charoonnart P, Gangnonngiw W, Withyachumnarnkul B. A novel and inexpensive application of RNAi technology to protect shrimp from viral disease. J Virol Methods. 2009;162(1-2):213-7.

20. Sambrook J, Russell DW. Purification of nucleic acids by extraction with Phenol:Chloroform. Cold Spring Harb Protoc. 2006;2006(1):pdb.prot4455.

21. Losen M, Frölich B, Pohl M, Büchs J. Effect of oxygen limitation and medium composition on escherichia coli fermentation in shake-flask cultures. Biotechnol Prog. 2004;20(4):1062-8.

22. Kahaki F, Babaeipour V, Memari H, Mofid M. High overexpression and purification of optimized bacterio-opsin from Halobacterium Salinarum R1 in E. coli. Appl Biochem Biotechnol. 2014;174(4):1558-71.

23. Theerawanitchpan G, Saengkrit N, Sajomsang W, Gonil P, Ruktanonchai U, Saesoo S, et al. Chitosan and its quaternized derivative as effective long
dsRNA carriers targeting shrimp virus in Spodoptera frugiperda 9 cells. J Biotechnol. 2012;160(3-4):97-104.

24. Thammasorn T, Somchai P, Laosutthipong C, Jitrakorn S, Wongtripop S, Thitamadee S, et al. Therapeutic effect of Artemia enriched with Escherichia coli expressing double-stranded RNA in the black tiger shrimp Penaeus monodon. Antiviral Res. 2013;100(1):202-6.

25. Manderson D, Dempster $R$, Chisti $Y$. A recombinant vaccine against hydatidosis: production of the antigen in Escherichia coli. J Ind Microbiol Biotechnol. 2006:33(3):173-82.

26. Zanette D, Dundon W, Soffientini A, Sottani C, Marinelli F, Akeson A, et al. Human IL-1 receptor antagonist from Escherichia coli: Large-scale microbial growth and protein purification. J Biotechnol. 1998;64(2-3):187-96.

27. Gupta P, Ghosalkar A, Mishra S, Chaudhuri TK. Enhancement of over expression and chaperone assisted yield of folded recombinant aconitase in Escherichia coli in bioreactor cultures. J Biosci Bioeng. 2009;107(2):102-7.

28. Lee J, Lee SY, Park S, Middelberg APJ. Control of fed-batch fermentations. Biotechnol Adv. 1999;17(1):29-48.

29. Shiloach J, Fass R. Growing E. coli to high cell density-A historical perspective on method development. Biotechnol Adv. 2005;23(5):345-57.

30. Collins T, Azevedo-Silva J, da Costa A, Branca F, Machado R, Casal M. Batch production of a silk-elastin-like protein in E. coli BL21(DE3): key parameters for optimisation. Microb Cell Fact. 2013;12:21.

31. Williams JA, Carnes AE, Hodgson CP. Plasmid DNA vaccine vector design: Impact on efficacy, safety and upstream production. Biotechnol Adv. 2009;27(4):353-70.

32. Zabriskie D, Wareheim D, Polansky M. Effects of fermentation feeding strategies prior to induction of expression of a recombinant malaria antigen inEscherichia coli. J Ind Microbiol. 1987;2(2):87-95.

33. Shekar M, Pradeep B, Karunasagar I. White spot syndrome virus: genotypes, epidemiology and evolutionary studies. Indian J Virol. 2012;23(2):175-83.

34. Marks H, Goldbach RW, Vlak JM, van Hulten MCW. Genetic variation among isolates of White spot syndrome virus. Arch Virol. 2004;149(4):673-97.

35. Marks H, van Duijse JJA, Zuidema D, van Hulten MCW, Vlak JM. Fitness and virulence of an ancestral White Spot Syndrome Virus isolate from shrimp. Virus Res. 2005;110(1-2):9-20.

36. Pradeep B, Karunasagar I. Fitness and virulence of different strains of white spot syndrome virus. J Fish Dis. 2009;32(9):801-5.

37. Lan Y, Lu W, Xu X. Genomic instability of prawn white spot bacilliform virus (WSBV) and its association to virus virulence. Virus Res. 2002;90(1-2):269-74.

38. Hoa TTT, Zwart MP, Phuong NT, Oanh DTH, de Jong MCM, Vlak JM. Mixedgenotype white spot syndrome virus infections of shrimp are inversely correlated with disease outbreaks in ponds. J Gen Virol. 2011;92(3):675-80.

\section{Submit your next manuscript to BioMed Central and we will help you at every step:}

- We accept pre-submission inquiries

- Our selector tool helps you to find the most relevant journal

- We provide round the clock customer support

- Convenient online submission

- Thorough peer review

- Inclusion in PubMed and all major indexing services

- Maximum visibility for your research

Submit your manuscript at www.biomedcentral.com/submit
C BioMed Central 